\title{
Historein
}

Vol $2(2000)$

Heterodoxies: Constructions of Identities and Otherness in Medieval and Early Modern Europe

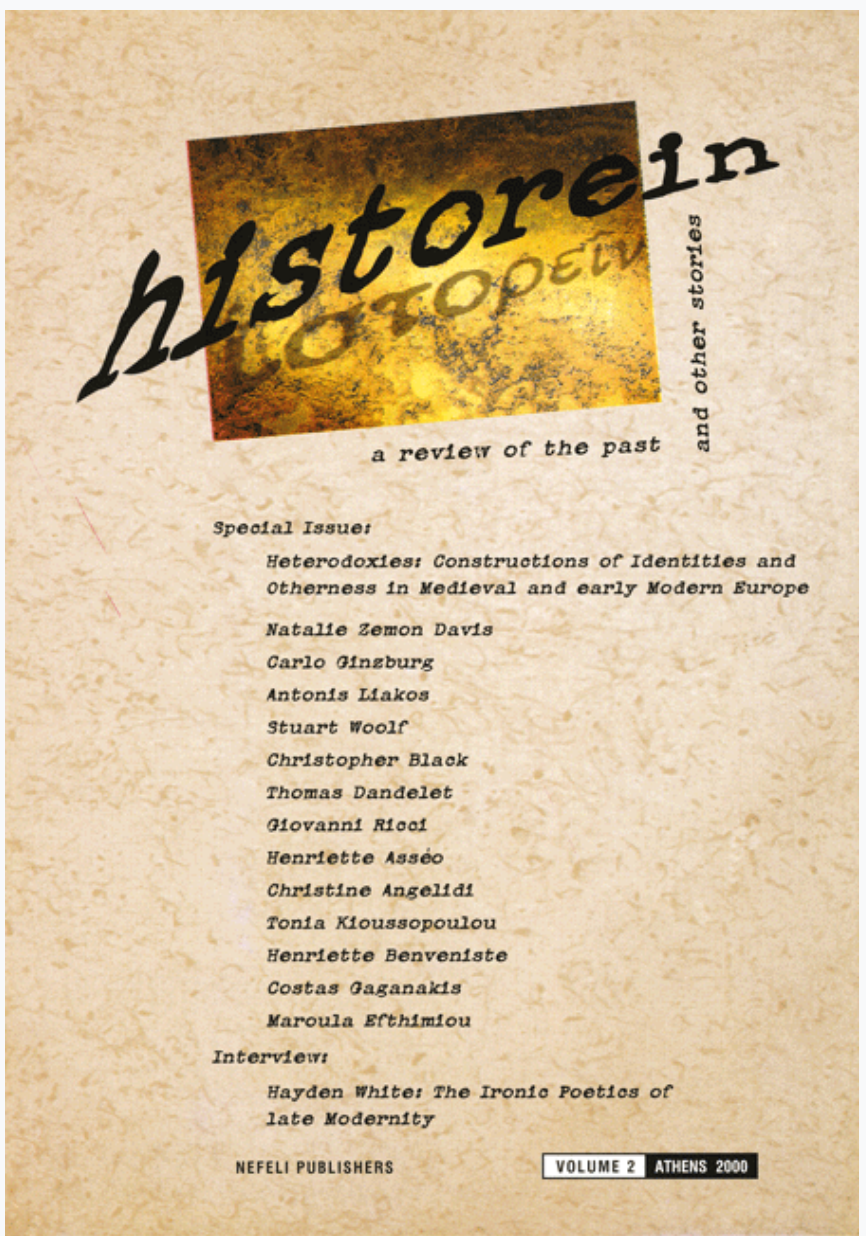

\section{Knowledge of Others and Self-Perceptions of European Identity}

Stuart Woolf

doi: $10.12681 /$ historein.112

Copyright () 2012, Stuart Woolf

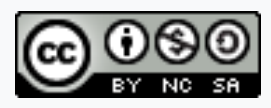

This work is licensed under a Creative Commons Attribution-NonCommercialShareAlike 4.0.

\section{To cite this article:}

Woolf, S. (2001). Knowledge of Others and Self-Perceptions of European Identity. Historein, 2, 55-64. https://doi.org/10.12681/historein.112 


\section{Knowledge}

\author{
of others
}

and

\section{self-perceptions}

of European

identity

\section{Stuart Woolf}

For a wheel to turn, for life to live, there is a need for impurities, and the impurities of impurities. There is a need for dissent, for differences, for a grain of salt, and of pepper. Primo Levi ${ }^{1}$

It is a truism of anthropology and psychology that perception of others is part of the process of the construction of the self. But whereas for psychology there is, in terms of the individual's mental equilibrium, a close and reciprocal relationship between Ego's perception of Others and Others' perception of the Ego, it is far from evident, in anthropological and historical experience, that such reciprocity has functioned in the construction of the collective self, not just in European but in any organized society. As Ignacio Sachs has noted, "the discourse about the 'other', as about the 'different', has always been impregnated with ethnocentrism, on everyone's part; an ethnocentrism that is the matrix of reciprocal antagonisms founded on judgements about the qualities of people, even before ideologies based on differentiation." ${ }^{2}$ It may well be (and it would be a comforting conclusion) that collective awareness of the perceptions of Others can lead to a more inclusive rather than exclusive construction of identity, for example, in relation to immigrants or the principles of citizenship.

There can be no doubt about the importance, as a research approach, of the theme of inclusion in the process of self-identification of a social group, so long as it does not ignore the dimension of exclusion. In this essay on European identity I am concerned with exclusion. I would suggest that the balance between the relative importance attributed by members of a group to inclusion or exclusion is conditioned to a notable degree by the sense of 
the vicinity or rival presence of the Other. Exclusive 'Europeanness', for example, has surfaced at particular moments of European history: in the guise of 'Christian Europe' crusading against the Muslims, in the Middle Ages; in the attribution to Europe of a uniquely superior and progressive culture, in the period of the rapid discovery and penetration of extra-European territories and societies, from the late eighteenth century until the first world war; in the often teleological affirmation of the historical continuity of a European cultural identity, commensurate with the major advances of the European Community/Union as an economic rival to the U.S.A. and Japan, in recent years.

In historiographical terms, it is not accidental that the claims and search for an identity common to all Europe became particularly insistent in coincidence with the second World War. For the war was experienced, -in Western intellectual and political circles, not just as a renewal of the internecine destructiveness of the previous world war, but as an unprecedented threat - nazism - to what had long been accepted as the values of European civilization. ${ }^{3}$ It constituted a reaction against the hegemonic national and nationalistic mould of historiography which was felt (probably not very consciously) to have contributed to the destruction of Europe through its relegation of the continent to the geographical arena of nation-state rivalry.

A cultural side-effect of nationalism in the nineteenth century was the consolidation of teleologically oriented nation-state historiographies that until recently narrated the history of Europe as that of its individual states and their international relations, reducing any sense of 'Europeanness' to its colonialist dimension. We need to distance ourselves from this nationalistic historicism, so successfully rooted from the late nineteenth century; but we must beware of the pitfall of substituting for it an equally historicist interpretation of the history of an idea of Europe, read backwards from the concerns of the present and hopes of the future. This is not to conclude that a history of Europe cannot be conceived and written, but that the conceptual and methodological approaches need to be updated, exploring (for example) the broad similarities in the forms of social organization for long periods of European history (such as feudalism), or the significance of the supra-national diffusion of information, whether among the educated (as with the itinerant scholars of medieval Europe or during the Enlightenment) or at the popular level.

The histories of Europe published as a response to the war's denial of European values sought to highlight the positive common elements that could be regarded as inherent in the historical evolution of Europe. In unconscious imitation of national state historiography, such works particularly contributions in recent decades - have fallen into the trap of assuming, and attempting to demonstrate, that (at least in embryonic form) an idea or an identity of Europe had always existed. ${ }^{4}$ It is not difficult to illustrate the artificiality and contradictions of reading the millenial history of Europe backwards in terms of its identity. ${ }^{5}$ Like national identities, it is possible to periodise the construction of a European identity, which took form from the latter half of the eighteenth century.

My concern in this essay is with the cultural humus out of which a self-conscious sense of European identity became explicit. Hence it is convenient to begin at the end, with a brief 
comment on the period when the idea of a European identity accelerated and crystallized in the half-century between the Enlightenment and the Revolutionary-Napoleonic years. ${ }^{6}$ A cultural hinterland was marked out, most explicitly by Voltaire but permeating the Enlightenment, in which the superiority of Europe to other civilizations was demonstrated on the basis of four very different criteria, all of which corresponded to the self-perceptions of western European intellectuals: the historical continuity of a specific European cultural tradition, originating in classical antiquity, with the hiccup of the 'barbaric' centuries then recovered from the Renaissance onwards; the dynamism of the European economy, compared to the 'staticity' of earlier and contemporary extra-European empires, which could be explained through the encouragement of individual entrepreneurship; the 'liberty' that, in contrast to 'oriental' (and other) 'despotisms', was assumed to characterize public governance in Europe; and the elaborately articulated forms of social manners, or civilités, that Norbert Elias has dubbed as the 'civilizing process'.

The 'Europe' of this cultural paradigm referred essentially and virtually exclusively to western Europe. It is important constantly to hold this present because of its implications in marking out frontiers (changeable over time) that permitted the exclusion of those parts of the continent that - whether in terms of religion (e.g. the Muslim Balkans) or of forms of polity or economy (e.g. Russia) - were incompatible with the paradigm. In this manner we can remove at least one filter from an exploration of the sources and mechanisms out of which the Enlightenment version of a European identity was constructed.

Such a shared cultural patrimony was transformed politically by the Revolutionary and Napoleonic elites in two very different ways. On the one hand, Bonaparte's military cum utilitarian-scientific invasion of Egypt legitimated policies of conquest in terms of the right, even the duty, of more 'advanced' nations to impose their rule on the more 'backward' areas of the world. On the other hand, the model of rational and informed enlightened administration that the Napoleonic elites had imposed on the greater part of Europe was seen retrospectively by liberals (once the danger of Bonapartist dictatorship had been removed) as the effective instrument to direct progress. The self-consciousness of European superiority, in a cultural sense, as well as in military and economic terms, underpinned Europe's conquest of the world. The elaboration and even more the application of this self-referential model obviously and continuously generated tension and problems of coherence, both in the ever more invasive European presence outside Europe and within the continent itself. There was a fundamental contradiction between the nineteenth century affirmation of the nation-state and the contention of a common European identity that continued to use the constituent cultural elements elaborated in the earlier period (with the addition of a reborn Christian sense of mission). This was resolved in practice (although never, it seems to me, at the intellectual or theoretical level) - at least until the explosion of 1914 - by separating the endemic rivalry and conflict of nationalism within Europe from a common front of European superiority (including, where appropriate, its white-settled extensions in North America, South Africa and Australasia) vis-à-vis the non-European world. 
I am concerned, in this essay, with the representation of others, both outside and within Europe, primarily in the early modern period. My propositions are exploratory and generalizing to the extreme; their justification is that they seem to me to provide signposts of the cultural terrain on which the self-representation of European identity was constructed during the Enlightenment. The theme needs to be explored in two different directions: on the one hand, the elaboration of commonplaces about different non-European peoples and their place in changing interpretations of the history of mankind; and, on the other, the process of consolidation of social rules about the ordering of society within Europe.

It is evident that knowledge of other, non-European societies was never a simple cumulative process. At the peak of Enlightenment confidence, the geographical discoveries and advances in scientific methods encouraged the optimistic belief that it was at last possible to reconstruct and discover all that was useful to know about the progressive stages through which humanity evolved. History, by itself, was inadequate, not so much because it was cloaked in myths and biblical fables, but because it was impotent before the invention of writing and hence could only account for a limited span of the evolution of mankind. Archaeology extended the possibilities of producing knowledge about the classical world; and indeed, by the end of the eighteenth century, about other ancient cultures, such as Egypt (the Rosetta stone was discovered by Bonaparte's expedition of 1799) or India. The new science of anthropology was intimately linked to the geographical discoveries: the first manual on how to observe primitive natives was prepared by the Société des Observateurs de l'Homme during the French Revolution as instructions for the captain of an expedition to the Pacific. ${ }^{7}$ Twenty years earlier, the potential of the new knowledge had already been expressed admirably by Edmund Burke in a letter to the Scottish historian, William Robertson:

We need no longer go to History to trace it in all its stages and periods. History from its comparative youth, is but a poor instructor. But now the Great Map of Mankind is unrolled at once; and there is no state or Gradation of barbarism and no mode of refinement which we have not at the same instant under our View. The very different Civility of Europe and of China; The barbarism of Tartary, and of Arabia. The Savage State of America, and of New Zealand. ${ }^{8}$

Such ebullience marked the apparent point of arrival of an opaque process of the passage of information, stories and legends about different regions of the non-European world that had been going on since antiquity through multiple and often unwritten channels. Until the early modern era the sources of information remain obscure. Ptolemy's mapping of the world, written in the second century A.D. and based on Greek works and the accounts of merchants and navigators of his city of Alexandria, was the basis of European cartography into the fifteenth century. During the middle ages, as Donald Lach has pointed out, Asia was viewed through Christianized versions of classical myths, "embellished with biblical allegories and newer geographical fantasies." The popular medieval image of the 'East' was the scenario for the legendary stories of Alexander of Macedonia, St. Thomas (Apostle of India), and Prester John (whose realm migrated from India 
to Africa in the fourteenth century). The accounts of Arab and Jewish travellers, like those of Marco Polo in the thirteenth century, were disbelieved. Neither the huge trade in spice, nor the stories of the Western merchants, sailors and carriers involved in it, dented the popular imagery of the East. Even as geographical knowledge expanded with the navigations of the fifteenth century, culminating in those of Vasco da Gama and Christopher Columbus, the cartographers did not abandon their insertion of mythical beasts and monsters, but merely displaced them to the numerous still unknown lands and waters of the world. ${ }^{9}$

For educated Europeans of the seventeenth and much of the eighteenth century, the rediscovery of antiquity, the Bible and early Christian history directed their curiosity and preoccupations. We know about the serious intellectual problems presented by the discovery of the Americas in a biblically-based interpretation of the history of mankind. The power of Islam in the seventeenth century was seen by some as punishment for the sins of the Christians (analogous to the need for the eternal presence of Jews as evidence of the sacrifice of Christ); by the eighteenth century, knowledge of the Near East (like calculations of the age of the world) relied heavily on the Bible; and travellers to the area sought to discover more about the classical and Biblical world because of the assumption that language and ways of life had remained unchanged since those times. ${ }^{10}$

The ways in which information about the non-European regions of the world was read were constantly mediated by their relationship to existing nearby realities and mental cosmographic schema. The availability of information became ever more abundant, as written accounts of travellers increased notably in the seventeenth century and exploded in the eighteenth. ${ }^{11}$ But not least because of the popularity of such travel books, the line between reality and fiction could be very thin in their accounts of the unusual and often exotic ways of life of other peoples. It is arguable that, apart from familiarizing Europeans with exotic place-names, the growth in supply of such literature reinforced the sense of the distance of these non-European peoples and cultures from their European readers: 'Orientalism', as Edward Said has illustrated, served to consolidate Europeans' self-image..'2 Written, and presumably oral descriptions of 'others' necessarily employed the language of forms of behaviour and social organization familiar to their European readers. The distinctions between natural and supernatural, concepts of time, transmitted memory, stories recounted in family or folk tales, were all pieces in a kaleidoscopic interpretation of the Other. A thick interplay of ways of reading, as indicated by Roger Chartier, replaced earlier simple models of elite and popular culture with a multitude of channels and intermediaries and a potential infinity of forms, as successive communities of readers took (and take) possession of texts, reading into them their own understanding. ${ }^{13}$ Even if exotic extraEuropean places are not particularly visible in the bibliothèque bleue and chapbooks, the success of the Arabian Thousand and One Nights or Gulliver's Travels clearly indicates the attraction of suspended belief for their readers, from the educated to the popular. By, and in large part due to, the Enlightenment, these multiple strands were woven into Edmund Burke's 'Great Map of Mankind' which rendered 'the very different Civility of Europe' coherently visible.

At the base of the attraction (and repulsion) for these extra-European regions and their societies 
was the contrast between the familiar and the unfamiliar, the known and the unknown. European 'civility' was understandable because it was known, and hence foreseeable in terms of social relations, rules and regularities; the diversity of other societies (cultural, linguistic and social) made them uncertain, unpredictable and hence potentially hostile or dangerous. The qualities attributed to the collective Other were the inverse of those of the European Self, and since the criteria of diversity are always set by the self-designated 'civilized' society, they could be culturally mobile, changing according to circumstances: American Indians changed from 'noble savages' to 'brutes' after their massacre of settlers in Virginia in $1622 .{ }^{14}$ Difference of physical appearance facilitated more drastic ethnical judgements (not just in European, but in other societies convinced of their superior civilization, both more ancient and contemporary), to the point of denying the common appurtenance to the human species: in ancient Egypt the term 'man' was limited to the Egyptians; in Africa, the word 'bantu' meant 'man', used as a contrasting self-description of this nomadic social group to the 'non-men' with whom they came into contact. Physical animal traits (including cannibalism) were attributed to 'inferior' peoples, above all slaves - and hence in the first instance to Africans. ${ }^{15}$

The language of this fundamental contrast between European self-perception and the representations of extra-European peoples began to be deployed with growing frequency from the sixteenth century, presumably because of the rapid expansion of geographical horizons. 'Civilized' had been opposed to 'barbarous' since classical Greece. Africa, in its blackness (physical and metaphorical) offered the stock contrast, equally for Christian Europeans and Muslim Arabs (although black Christian Prester John, once his realm was translated to Africa, must have generated some perplexity among the former).$^{16}$ But from the outset the use of the term 'barbarous' was ambivalent, to the point that the vocabulary changed in meaning over the centuries, as it became increasingly evident that not all other peoples were barbarians. Brazilian Indians for Montaigne, like Shakespeare's Caliban in The Tempest, may have been barbarians in their life-style, but only in the sense that they continued to live close to an original simplicity, ruled by the laws of nature, outside the corrupting effects of civilized society. ${ }^{17}$ There was recognition, already in Garcilasa de la Vega's early seventeenth century description of pre-Columbian America, that some non-civilized peoples possessed a history, albeit at an inferior or earlier stage of the evolution of humanity. ${ }^{18}$ The Dutchman Pieter de Maries found it difficult to reconcile how Gold Coast Africans, "although they are altogether wild, rough, and uncivill, having neither scripture nor bookes, nor any notable lawes that might be set downe," were commerciallyminded, with agriculture, manufactures, markets and gold currency, and a system of elective rulers. ${ }^{19}$ Since techniques, property, economic organization, written language, formal laws and order, religion and life-styles (dress, food, rules of etiquette, sexual behaviour) were the primary criteria by which to judge the quality of strange peoples, contradictions were inevitable in the bare contrast of civilized to barbarian and became increasingly frequent as travellers and descriptions multiplied. China was, of course, the classic instance, as it met, and in many ways surpassed, virtually all the criteria of European civilization; as the Jesuit and other missionary reports multiplied in the seventeenth century, an explanation was found in an innate reverence for authority. ${ }^{20}$ 
Distinctions were made, which ultimately were to be integrated during the Enlightenment into its hierarchical classificatory explanation of the history of the world. The first distinction was recognition that 'savages' constituted, as it were, a separate sub-category of barbarians. Both were 'wild'. But the former had saving qualities, in the earlier period through their approximation to an ideal state of nature, by the late Enlightenment as living evidence of an earlier stage of the history of mankind. Hakluyt had already recorded a report of 1566 from West African 'Guinea' that implied such of civilized development. ${ }^{21}$ For Enlightenment anthropologists, for whom the evidence of the successive stages of the evolution of mankind had survived, as it were, in frozen form, irrespective of time and space, Pacific 'savages' became scientific objects worthy of study.

The second distinction, forward rather than backward-looking, had already been formulated by Montesquieu when he contrasted 'oriental despotism' to the principle of formally established limits to absolute power - the characteristic European liberty of public governance. ${ }^{22}$ But far more all-embracing (not least because it removed the epistemological challenge of Chinese civilization) was the explanation in the language of market and entrepreneurship, following Adam Smith, that was to become a refrain in the nineteenth century: it was the economic dynamism of Europe that distinguished its civilization from those of the static, unchanging 'oriental' empires. European perceptions of non-European peoples and cultures were now set into an apparently scientific mould that, in the following century, was to become increasingly rigid and ultimately brittle.

I proposed, earlier in this essay, that the cultural terrain out of which a European identity was constructed during the Enlightenment requires an exploration in two directions. The second field of enquiry relates to the conventions that bounded the social world of Western European communities in the early modern period. The subject is so vast that only the most summary comments are possible here, related exclusively to what seems to me the common underlying attitude towards strangers within Western European societies and their perceptions of extraEuropean peoples.

In this instance, the social historiography of recent decades has made apparent the continuities from the middle ages in mental attitudes towards the 'stranger'. ${ }^{23}$ As Bronislav Geremek has explained, the social imagination of medieval man - despite the ever - present realities of physical mobility - placed great stress on the familiar, on the regularity of a fixed social order and behaviour, based on ties of kin and neighborhood. Fear of the unknown extended far beyond the real perils of voyages to the uncertain boundaries between the natural and the supernatural - on the one hand, the unknown companions of travel and constant danger of bandits, on the other, the forest wolf and orco of popular stories. Spatial mobility was potentially a threat to social order: hence the diffidence towards 'inside' and 'outside' carried moral connotations that extended beyond their spatial reality to the social ordering of society. Established domicile was a primary qualification, as it guaranteed the necessary benchmarks of identity of kin, neighbours and guild - even if practitioners of particular, socially degrading professions were marginalized because of their violation of social, religious or cultural taboos, like prostitutes, butchers and shepherds. Day-labourers, often immigrants, were only partially accepted because they failed to 
meet the established criteria. In the religious terms of the Christian world, all who were different - pagans, savages, infidels - were excluded. Jews, despite their residence, were permanently excluded, as their existence was required as testimony of Christian redemption. Itinerant strangers were treated with marked diffidence, from non-identified travellers passing through to colporteurs and beggars; and Gypsies, some of whom might have wished to be resident, were similarly excluded since the late middle ages.

Such attitudes not only carried through in the early modern period. They became harsher. The more elaborate the corporative and status stratification of early modern societies, the greater the premium on social recognition, whether negotiated through formal or informal networks. The increasingly harsh treatment of the poor between the sixteenth and eighteenth centuries offers a window onto the hardening of lines and the distrust of the stranger. It is not by chance that the stories of organized bands, even guilds of cheating beggars circulated from the late fifteenth century. To be a sans aveu, without family, domiciliation or skill, was to risk exclusion and punishment. A parallel social hierarchy of deserving and undeserving poor was constructed, from the shamefaced poor and his counterpart, the fainéant, down to the licensed resident beggar alongside the dishonest and potentially dangerous vagabond. ${ }^{24}$

What is the connection between perceptions of non-European peoples and social attitudes in early modern Europe? I would suggest that the lines of social distinction and hence of inclusion/exclusion were solidifying in the early modern period. As they became more rigid, alongside the explosively widespread intolerance of religious divides, there was a hardening of attitudes towards both the stranger at home and the peoples so different from oneself. As, within European societies, the medieval faith in old women's healing powers had been displaced by the seventeenth century witch craze, so the scholarly respect for Islamic learning of the Middle Ages had been drowned in the sea of hostility towards Muslims.

These brief comments have been concerned with the broad cultural shifts that provided the humus for the growth of a sense of the distinctiveness of Europe. They should not be read as necessarily leading to a single - and even less a uniform - European identity. The European self-image that emerged between the Enlightenment and the Restoration was not fixed and unchanging; for collective identities are composite and contradictory, displaying different faces according to specific situations and occasions. This became very apparent in the course of the nineteenth century when the structural changes in the relationship between Europe and the world, political, technological and economic, radically accentuated the sense of European superiority over other peoples.

Since Arnold Toynbee, over half a century ago, ${ }^{25}$ modern historiography, even on the grand scale of the history of civilizations, has tended to ignore the power of the sense of Otherness. This derives, I believe, in good part from the dominant concern of contemporary historiography to document and explain change in terms of progress, compounded by often uncritical adoption of social science concepts of modernization. Even so wide-ranging and non-Eurocentric a historian as W.H. McNeill argues that traders, itinerant artisans, sailors and adventurers - 'strangers' - 
played a more crucial role than conquests in the passage of food crops and technologies between different cultures; that diversity and "restless changeability" may be associated with complex, unstable societies, but are the prerequisites for cultural innovation in civilized communities; that "polyethnic hierarchy" is far more typical than ethnic and cultural homogeneity in the historical record. ${ }^{26}$ Impurity, as Primo Levi has put it, is the essence of life. We live in an age that has revealed only too disastrously the consequences of dogmatically imposed beliefs in purity and homogeneity. But precisely for that reason, as historians, we cannot afford to ignore "how recalcitrant humankind is to the uncertainty and changeability of civilized life." ${ }^{27}$ For it is as much the sense of recalcitrance as the arrogance of progress that explains the fears and hostility that, historically, have underlaid the reciprocal perceptions of collective Self and Other.

1 P.Levi, Il sistema periodico. Torino: Einaudi, 1975, p. 35.

2I.Sachs, 'Selvaggio/barbaro/civilizzato', Enciclopedia. Torino: Einaudi, vol.xii, 19xx, p. 671.

${ }^{3}$ H.A.L.Fisher, A History of Europe. London: E.Arnold, 1935; E.Barker, G.Clark and P.Vaucher (eds.), The European Inheritance, 3 vols. Oxford: Oxford University Press, 1954; F.Chabod, Storia dell'idea d'Éuropa (academic course delivered in 1943-44). Bari: Laterza, 1961; J. Bowles, The Unity of European History,London: Cape, 1948; 0.Halecki, The Limits and Divisions of European History. London-New York: Sheed and Ward, 1950.

It is worth recalling that Henri Pirenne drafted his Histoire de l'Europe (Paris: Alcan, 1936) in a prisoner-ofwar camp during the first World War.

${ }^{4}$ For example, J.Duroselle, L'idée d'Europe dans l'histoire. Paris: Denoel, 1965; idem, L'Europe: histoire de ses peuples. Paris, 1990; J. van der Dussen, K.Wilson (eds.), The History of the Idea of Europe. London: Routledge, 1995; F.Curcio, Europa. Storia di un'idea. Milano: Vallecchi, 1958.

${ }^{5}$ The monographic issue of Past and Present, 137 (1992)('The Cultural and Political Construction of Europe'), offers a clear illustration of these difficulties. For a discussion of some of the contradictions, S.Woolf, 'Europa, una sola storia, un'unica identità?', in F.Cerutti (ed.), Identità e politica. Bari-Roma: Laterza, 1996, pp. 216-22.

${ }^{6}$ For the following paragraphs, S.Woolf, 'The Construction of a European World-View in the Revolutionary- 
Napoleonic Years', Past and Present, 137 (1992), pp. 72-101.

${ }^{7}$ J.Copans and J.Jamin (eds.), Aux origines de l'anthropologie française: les mémoires de la Société des Observateurs de l'Homme en l'an VIII. Paris, 1978.

${ }^{8}$ P.J.Marshall and G.Williams, The Great Map of Mankind. British Perceptions of the World in the Age of Enlightenment. London: Dent, 1982, p. iii.

${ }^{9}$ D.F.Lach, Asia in the Making of Europe, vol.1, The Century of Discovery. Chicago-London: The University of Chicago Press, 19xx, pp. 16-36.

${ }^{10}$ Marshall and Williams, Great Map of Mankind, pp. 10-13; L.Hanke, Aristotle and the American Indians. London: Hollis and Carter, 1959.

${ }^{11} \mathrm{~A}$ revealing indicator of the relative importance of different regions of the world, as seen through the eyes of (real and armchair) travellers are the three volumes of G.Boucher de la Richarderie, Bibliothèque universelle des voyages. Paris, 1808.

${ }^{12}$ E.W.Said, Orientalism. Western Concepts of the Orient. London: Routledge and Kegan Paul, 1978.

${ }^{13}$ R.Chartier, Forms and Meanings. Texts, Performances, and Audiences from Codex to Computer. Philadelphia: Uiversity of Pennsylvania Press, 1995.

${ }^{14}$ Marshall and Williams, Great Map of Mankind, pp. 28-29.

${ }^{15}$ Sachs, 'Selvaggio/barbaro/civilizzato', cit., particularly p.676, where he queries whether the term 'Christian dogs' was purely rhetorical for Islam, where the human species was identified almost exclusively with the 'faithful'.

${ }^{16}$ ibid., p.674.

${ }^{17}$ M.de Montaigne, Essais, xx, 1580.

${ }^{18}$ Garcilaso de la Vega, Comentarios que tratan del origen de los Yucas, xxx, 1609.

${ }^{19} \mathrm{P}$. de Maries, 'Description and historicall declaration of the golden Kingdome of Guinea' (16xx), cited in Marshall and Williams, Great Map of Mankind, p. 36.

${ }^{20}$ Marshall and Williams, Great Map of Mankind, pp. 20-21.

${ }^{21}$ ibid., p.37.

${ }^{22}$ Ch.de Montesquieu, L'esprit des lois, xxx, 1748, ch.xx [Despotisme oriental].

${ }^{23}$ B.Geremek, 'L'uomo emarginato', in J.Le Goff (ed.), L' uomo medievale. Bari-Roma: Laterza, 1987; J. LeGoff, L'imaginaire médiéval. Paris, 1985.

${ }^{24}$ S.Woolf, The Poor in Western Europe in the Eighteenth and Nineteenth Centuries. London: Methuen, 1986, pp. xx

${ }^{25}$ A.Toynbee, A Study of History, 10 vols. London: Oxford University Press, 1934-54.

${ }^{26}$ W.H.McNeill, The Shape of European History. New York-London: Oxford University Press, 1974, pp. 30-43; idem, Polyethnicity and National Unity on World History. Toronto: Toronto University Press, 1986.

${ }^{27}$ McNeill, Shape of European History, p. 40. 